Pak. j. sci. ind. res. Ser. B: biol. sci. 201154 (3) 136-141

\title{
The Composition and Relative Abundance of Fish Species in a Mangrove Creek in the Niger Delta, Nigeria, Based on Different Types of Gear
}

\author{
Blessing Julius Oribhabor ${ }^{a *}$, Mfon Timothy Udo ${ }^{a}$, Lawrence Etima and \\ Ahmed Sardauna Adisa-Bolantab \\ ${ }^{a}$ Department of Fisheries and Aquaculture, Faculty of Agriculture, University of Uyo, \\ P.M.B. 1017, Uyo, Akwa Ibom State, Nigeria \\ ${ }^{\mathrm{b}}$ African Regional Aquaculture Centre, Nigerian Institute for Oceanography and Marine Research \\ (ARAC/NIOMR), PMB 5122, Port Harcourt, Nigeria
}

(received May 5, 2010; revised September 12, 2010; accepted October 2, 2010)

\begin{abstract}
The composition and relative abundance of fish species assemblage of a mangrove creek in the Niger Delta, Nigeria based on different types of gear was assessed at four stations between November 2004 and June 2006. The overall community structure was made up of 25 species of 16 families. Visual observation showed that tilapia species comprising of Sarotherodon melanotheron and Tilapia guineensis were the most dominant species. Samples from baited entrance traps indicated that $S$. melanotheron dominated T. guineensis. Samples from baited hook and line, and cast net showed dominance of $P$. elongatus followed by $P$. quadrifilis. (The baited hook and line is commonly used by the fishers because it is effective in catching diversity of species, except that it is unable to catch bottom feeders such as mullets and tilapia species). Funnel entrance trap had the highest species selectivity, catching only tilapia species. Cast net was more selective in species catch than baited hook and line, but it was effective in catching both pelagic and benthic species. Among the fish species, members of the families: Sciaenidae, Polynemidae, Ariidae, Monodactylidae and Cichlidae were permanent residents; Carangidae, Luthjanidae and Serranidae were temporary residents; while Elopidae, Gobiidae, Dasyatidae, Cynoglossidae, Sphyraenidae and Trichiuridae were rare species.
\end{abstract}

Keywords: composition, fish species, mangrove creek, Niger delta

\section{Introduction}

Knowledge of fish biology and species composition of different water bodies is necessary to enhance the management of water resources (Okereke, 1990). Niger Delta is located in the Southern part of Nigeria bordering the Atlantic Ocean in the Gulf of Guinea ecoregion. It is a flood plain of over $70,000 \mathrm{sq} \mathrm{km}$. The environment has been reported to be highly diverse and sensitive being the home of the largest stands of mangrove in Africa (over 1 million ha) and the fourth largest in the world (Spalding et al., 1997). The relative contribution of mangrove-related species to total fisheries catch is significant (Islam and Ikejima, 2010). Fisheries in and around mangroves provide direct employment to about 0.5 million fishermen worldwide (Matthes and Kapetsky, 1988). However, mangroves have declined due to increasing pressures from human activities including over-harvesting, aquaculture and coastal development (Alongi, 2002). The significant threat of oil pollution, over-exploitation of fisheries and mangrove resources

*Author for correspondence; E-mail: oribhaborbless@yahoo.com among other environmental pressures coupled with poor interest and recognition for brackish water bodies and aquaculture pose a great danger to the sustainability of Nigeria's brackish waters and diverse fish resources, and consequently the coastal communities of the nation (Oribhabor et al., 2005).

The importance of mangroves as nurseries has been one of the reasons advanced to support its conservation and management (Sheridan and Hays, 2003). There have been warnings, that supportive data have not been collected and that fish and decapods use of mangroves may not be the same in all areas of the globe (Hoss and Thayer, 1993; Chong et al., 1990). For effective conservation and management of mangroves, it is necessary to synthesize biological and socio-economic information on mangrove processes and values, and bring this to the attention of policy-makers for community development (Walters et al., 2008). The earlier records of mangrove fisheries were those of Blabber and Blabber (1980); Blabber (1980), Day (1974), Austin (1971), Boeseman (1963) and Inger (1955). Fish studies 
on Nigerian coastal waters include those of Chindah and Tawari (2001); King (1996a; 1996b); Chinda and Osuamkpe (1994); Wright (1986); Fagade and Olaniyan (1974; 1972). The Buguma Creek has been used by the Federal Government of Nigeria in collaboration with FAO in 1963 for pilot investigation of the possibility of converting mangrove swamps into brackish water fish farms. Oribhabor and Ogbeibu (2010) have assessed the impact of anthropogenic activities on the predatory fishes of the creek. This paper is the first to document the composition and relative abundance of fish species in Buguma Creek, based on different types of gear.

Study area. The Buguma Creek is located Southeast of the Niger Delta between longitude $6^{\circ} 47^{\prime} \mathrm{E}$ and $6^{\circ}$ $59^{\prime} \mathrm{E}$, and latitude $4^{\circ} 31^{\prime} \mathrm{N}$ and $4^{\circ} 59^{\prime} \mathrm{N}$ (Fig. 1) in Asari-Toru Local Government Area of Rivers State. The Buguma Creek system consists of the main creek channel and associated interconnecting creeks, which inter-connect and surround Buguma and Ido communities. The Buguma Creek serves as a source of tidal water for the Nigerian Institute for Oceanography and Marine Research/Buguma Brackish Water Experimental Fish Farm, which was constructed between 1963 and
1966 under the auspices of the FAO. The New Calabar River brings the salty ocean water as tidal flows diurnally to the fish ponds (Dublin-Green and Ojanuga, 1999). A more detailed description of the study area and water quality has been given by Oribhabor and Ogbeibu (2009a; 2009b); Ogbeibu and Oribhabor (2008).

\section{Materials and Methods}

The fish species composition and relative abundance of Buguma Creek fishes in Niger Delta, Nigeria were conducted based on different types of gear. Fish samples were collected monthly at four stations, at flood tides during the period November 2004 to June 2006. Sampling was conducted between 0800 and $1700 \mathrm{~h}$ on each sampling day for $6 \mathrm{~h}$, depending on the flow and ebb of tide.

Baited hook and line were used throughout the sampling duration at stations 1, 3 and 4; cast-net was used at station 1 from January to October, 2005; while baited funnel entrance traps were fortnightly used at stations 1 and 2 specifically for tilapia species from August to December, 2005. Fish samples were pooled based on gear, ice-packed after capture, kept chilled under

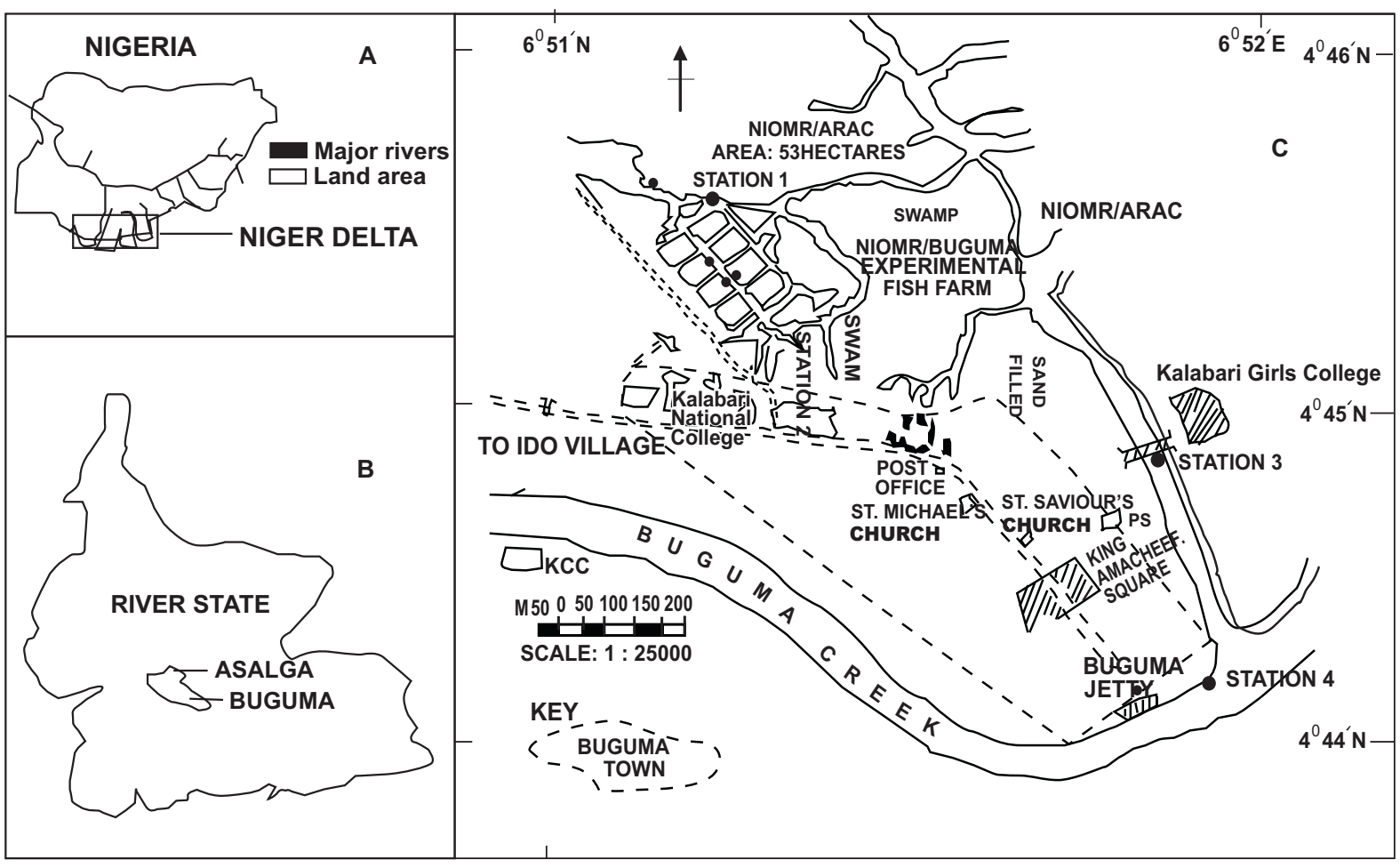

Fig. 1. Map of the study area: A : Nageria showing Niger delta, D - Rivers state showing Buguma, C. The study creek showing study station. 
ice-blocks in a plastic cooler and immediately transported to the laboratory. In the laboratory, fish specimens were sorted and identified to the species level using the keys and descriptions of Olaosebikan and Raji (2004); Teugels et al. (1992); Schneider (1990) and enumerated. Visual observation of extraneous fish species periodically harvested from two associated recruitment ponds of Nigerian Institute for Oceanography and Marine Research/Buguma Brackish Water Experimental Fish Farm was also carried out during the study period.

\section{Results and Discussion}

The overall community structure was made up of 25 species in 16 families (Table 1). There is no 'best' method for sampling fishes within mangrove habitats (Faunce and Serafy, 2006). Three sampling gears: baited hook and line, castnet, baited funnel entrance trap coupled with visual observation were used in this study because samples from the most environments are drawn blind with little or no study of the response of the fishes to sampling gear (Bagenal, 1978).

Among the fishing gears, funnel entrance trap was found to have high species selectivity, catching only tilapia species (Fig. 2). A total of 20 species in 14 families, and 16 species in 12 families were recorded for baited hook and line and castnet, respectively (Fig. 3 and 4). Although cast-net was more selective in species catch than baited hook and line it is effective in catching both pelagic and benthic species, unlike baited hook and line, which is specialized in catching only predatory species. Although catch composition varied with geographical habitat and the type of fishing gear and effort, the relatively low diversity found in the present study may in part indicate the over-exploitation of resources, resulting in destruction of habitat and consequent loss of species diversity (Islam and Ikejima, 2010).

Visual observation showed that tilapia comprising of $S$. melanotheron and $T$. guineensis were the most dominant species. Samples, from baited entrance traps (Fig. 2) indicated that S. melanotheron (306 individuals) dominated T. guineensis (136 individuals). The dominance of tilapia could be attributed to their prolific precocious breeding habit, ready availability of mud from which they derive their food, and euryhaline nature. Samples from baited hook and line (Fig.3), and castnet (Fig. 4) showed dominance of P. elongatus followed by $P$. quadrifilis. Differences in dominant species observed among the fishing gears are in conformity with the finding of Boromthanarath et al. (1991), who noted that dominant species differed by fishing gear types and methods. The baited hook and line fishing is commonly used by fishermen in Buguma because it is effective in catching diverse species, except that it is unable to catch bottom feeders such as mullets and tilapia species. Though quite selective by species, and to a considerable extent by size, in some situations, line fishing may be the most productive (Bagenal, 1978). Also in many of its forms, it can be conducted successfully by a single fisherman.

The low habitat diversity limits the number of fish species inhabiting tidal mangrove creeks (Krumme et al., 2004). Although low number of species was

Table 1. Checklist of fish species collected from Buguma Creek

\begin{tabular}{|c|c|}
\hline Family & Species \\
\hline Ariidae & Arius gigas (Boulenger, 1911) \\
\hline Carangidae & $\begin{array}{l}\text { Caranx latus (Agassiz in Spix \& Agassiz, } \\
\text { 1831) }\end{array}$ \\
\hline Cichlidae & $\begin{array}{l}\text { Sarotherodon melanotheron (Rüppell, 1852), } \\
\text { Tilapia guineensis (Güinther, 1862) }\end{array}$ \\
\hline Cynoglossidae & Cynoglossus senegalensis (Kamp, 1858) \\
\hline Dasyatidae & Dasyatis margarita (Günther, 1870) \\
\hline Elopidae & Elops lacerta (Valenciennes, 1846) \\
\hline Gobiidae & Gobius sp. (Peters, 1876) \\
\hline Haemulidae & $\begin{array}{l}\text { Plectorhnchus macrolepsis (Boulenger, 1899), } \\
\text { Pomadasys jubelini (Cuvier, 1831) }\end{array}$ \\
\hline Lutjanidae & $\begin{array}{l}\text { Lutjanus agennes (Bleeker, 1863), } \\
\text { Lutjanus goreensis (Valenciennes, 1830) }\end{array}$ \\
\hline Monodactylidae & Psettias sebae (Cuvier, 1831) \\
\hline Mugilidae & $\begin{array}{l}\text { Liza falcipinnis (Valenciennes, 1836), } \\
\text { Mugil cephalus (Linnaeus, 1758), } \\
\text { Mugil curema (Valenciennes, 1836) }\end{array}$ \\
\hline Polynemidae & Polydactylus quadrifilis (Cuvier, 1829) \\
\hline Sciaenidae & $\begin{array}{l}\text { Argyrosomus regius (Asso, 1801), } \\
\text { Pseudotolithus (Fonticulus) elongatus } \\
\text { (Bowdich, 1825), } \\
\text { Pseudotolithus (Pseudotlithus) senegalensis } \\
\text { (Bleeker, 1863) }\end{array}$ \\
\hline Serranidae & $\begin{array}{l}\text { Epinephelus aeneus (Geoffray St Hilaire, } \\
1809 \text { ) }\end{array}$ \\
\hline Sphyraenidae & $\begin{array}{l}\text { Sphyraena afra (Peters, 1844), } \\
\text { Sphyraena guachancho (Cuvier, 1829), } \\
\text { Sphyraena sphyraena (Linnaeus, 1758) }\end{array}$ \\
\hline Trichiuridae & Trichiurus lepturus (Linnaeus, 1758) \\
\hline
\end{tabular}


recorded for Buguma Creek, all mangrove and estuarine systems are similar in that, they have relatively few species that are clearly dominant in abundance (Tongnunui et al., 2002).

Among all the fish species, members of the families; Sciaenidae, Polynemidae, Ariidae, Monodactylidae, Mugilidae and Cichlidae were permanent residents. Members of the families; Carangidae, Lutjanidae and Serranidae were temporary residents, while those of

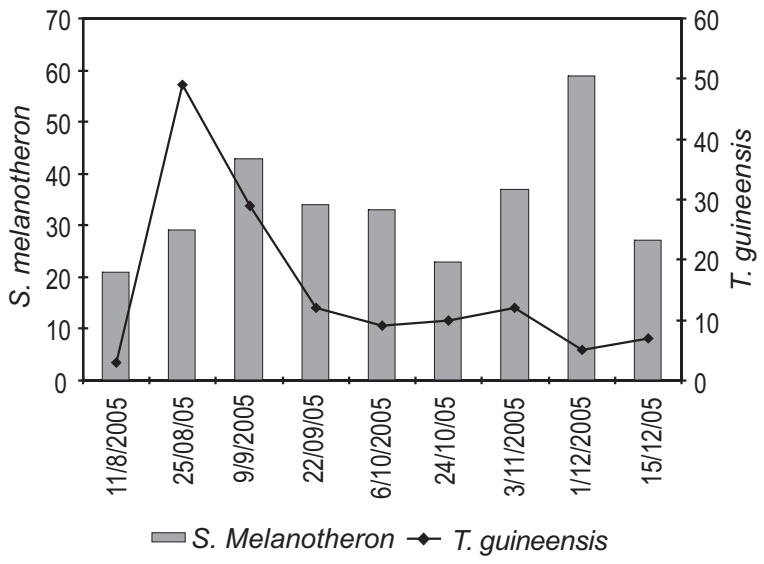

Fig. 2. Spatial and temporal variation in the relative abundance of the species caught with baited funnel entrance trap.

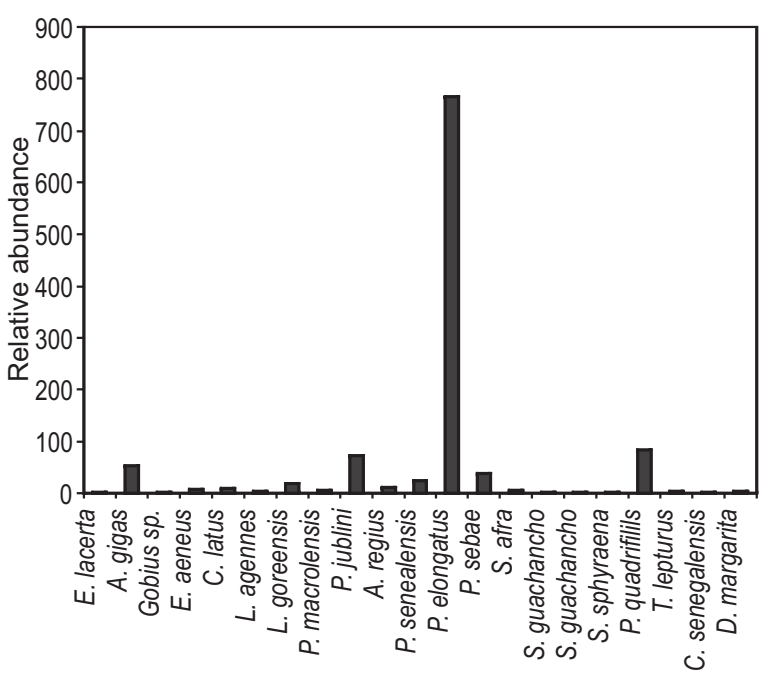

Fig. 3. Relative abundance of fish species caught with baited hook and line, November 2004 to June, 2006.

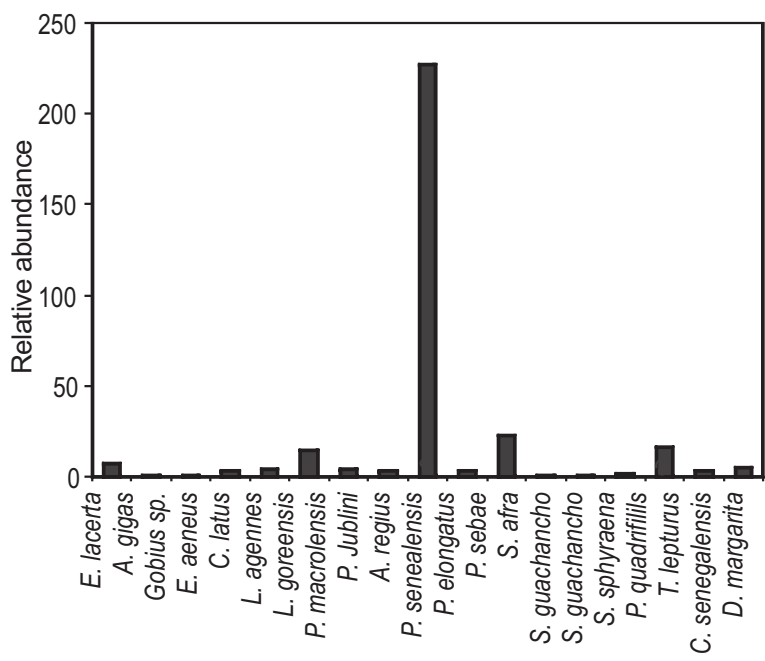

Fig. 4. Relative abundance of fish species caught with cast net, January to October, 2005.

the families; Elopidae, Gobiidae, Dasyatidae, Cynoglossidae, Sphyraenidae and Trichiuridae were rare species. Most fishes encountered in this study were sub-adults.

The number of species (25) recorded is high when compared to the 9 species of Wright (1986) for shallow water creeks of a Nigerian mangrove. About 30 species were reported in the Kaper mangrove in Malaysia (IPIECA, 1993). Davis (1988) caught 38 species in Austria, Krumme et al. (2004) caught 40 species in small intertidal mangrove creeks in Northern Brazil. Compared with other mangrove and estuarine systems, these records are low. A pool of all the species recorded in Lagos Lagoon, Nigeria over time revealed 115 species (Oribhabor and Ezenwa, 2005). Other high species record of mangrove and estuarine systems are 55 species (Beumer, 1978), 83 species (Little et al., 1988), 128 species (Kimani et al., 1996), 66 species (Laroche et al., 1997) and 135 species (Tongnunui et al., 2002).

\section{References}

Alongi, D.M. 2002. Present state and future of the worlds mangrove forests. Environmental Conservation, 29: 331-349.

Austin, H.M. 1971. A survey of the ichthyofauna of the mangroves of Western Puerto Rico during December 1967 - August 1968. Caribbean Journal of Science, 11: $27-39$.

Bagenal, T. 1978. Methods for Assessment of Fish Production in Fresh Waters, $3^{\text {rd }}$ edition, 365 pp., 
Blackwell Scientific Publications, Oxford, UK. Beumer, J.P. 1978. Feeding ecology of four fishes from a mangrove creek in north Queensland, Australia. Journal of Fish Biology, 12: 475-490.

Blabber, S.J.M. 1980. Fish of the trinity inlet system of north Queensland with notes on the ecology of fish fauna of tropical Indo-Pacific Estuaries. Australian Journal of Marine and Freshwater Research, 31: 137-146.

Blabber, S.J.M., Blaber, T.G. 1980. Factors affecting the distribution of juvenile estuarine and inshore fish. Journal of Fish Biology, 17: 143-162.

Boeseman, M. 1963. An annotated list of fishes from the Niger Delta. Zoologische Verhandelingen (Leiden), 61: 1-54.

Boromthanarath, S., Cobb, S., Lee, V. 1991. Coastal Management in Pak Phanang: A Historical Perspective of the Resources and Issues. Coastal Resources Institute, Prince of Songkla University, Hat Yai.

Chindah, A.C., Tawari, C.C.B. 2001. Comparative study of different gill net mesh sizes in the exploration of Bonga fish (Ethmalosa fimbriata) and sardines (Sardinella eba) in Brass coastal waters, Bayelsa State, Nigeria. Journal of Applied Sciences and Environmental Management, 5: 17-24.

Chindah, A.C., Osuamkpe, A. 1994. The fish assemblage of the lower Bonny River Niger Delta, Nigeria. African Journal of Ecology, 32: 58-65.

Chong, V.C., Sasekumar, A., Leh, M.U.C., D’Cruz, R. 1990. The fish and prawn communities of a Malaysian coastal mangrove system, with comparison to adjacent mud flats and inshore waters. Estuarine Coastal and Shelf Science, 31: 703-722.

Davis, T.L.O. 1988. Temporal patterns in the fish fauna entering a tidal swamp system in tropical Australia. Environmental Biology of Fishes, 21: 161-172.

Day, J.H. 1974. The ecology of Marrumbene estuary, Mozambique. Transactions of the Royal Society of South Africa, 41: 43-97.

Dublin-Green, C.O., Ojanuga, A.G. 1999. The problem of acid sulphate soils in brackish water aquaculture. Nigerian Institute for Oceanography and Marine Research Technical Paper No. 45.

Fagade, S.O., Olaniyan, C.I.O. 1974. Seasonal distribution of the fish fauna of the Lagos Lagoon. Bulletin de IFAN Series A., 36: 244-252.

Fagade, S.O., Olaniyan, C.I.O. 1972. The biology of the West African Shad, Ethmalosa fimbriata (Bowdich) in Lagos Lagoon, Nigeria. Journal of
Fish Biology, 4: 519-533.

Faunce, C.H., Serafy, J.E. 2006. Mangroves as fish habitat: 50 years of field studies. Marine Ecology Progress Series, 318: 1-18.

Hoss, D.E., Thayer, G.W. 1993. The importance of habitat to early life history of estuarine dependent fishes. American Fisheries Society Symposium, 14: 147-158.

Inger, R.E. 1955. Ecological notes on the fish fauna of a coastal drainage of North Borneao. Fieldiana Zoology, 37: 47-90.

IPIECA. 1993. Biological impacts of oil pollution, mangroves. IPIECA Report series Volume 4. International Petroleum Industry Environmental Conservation Association, London, UK.

Islam, M.S., Ikejima, K. 2010. Gear type, species composition and economic value of fisheries in the mangroves of Pak Phanang, Thailand. Wetlands Ecology and Management, 18: 27-36.

Kimani, E.N., Mwatha, E.O., Wakwabi, J.M., Ntiba, J.M., Okoth, B.K. 1996. Fishes of a shallow tropical mangrove estuary, Gazi, Kenya. Marine and Freshwater Research, 47: 857-868.

King, R.P. 1996a. Some aspects of the population dynamics of Ilisha africana (Bloch, 1795) Teleoster Clupeidae in Qua Iboe Estuary, Nigeria. Journal of Aquatic Sciences, 11: 17-24.

King, R.P. 1996b. Length-weight relationship of Nigerian coastal water fishes. Naga, ICLARMQ, 19: 53-58.

Krumme, U., Saint-Paul, U., Rosenthal, H. 2004. Tidal and diel changes in the structure of a nekton assemblage in small intertidal mangrove creeks in Northern Brazil. Aquatic Living Resources, 17: 215-229.

Laroche, J., Baran, E., Rasoanandrasana, N.B. 1997. Temporal patterns in a fish assemblage of a semi arid mangrove zone in Madagascar. Journal of Fish Biology, 51: 3-20.

Little, M.C., Reay, P.J., Grove, S.J. 1988. The fish community of an East African mangrove creek. Journal of Fish Biology, 32: 729-747.

Matthes, H., Kapetsky, J.M. 1988. Worldwide compendium of mangrove-associated aquatic species of economic importance. FAO Fishers Circular No. 814: 236.

Ogbeibu, A.E., Oribhabor B.J. 2008. The physical and chemical hydrology of a Niger delta tidal creek, Nigeria. Tropical Freshwater Biology, 17: 63-88.

Olaosebikan, B.D., Raji, A. 2004. Field Guide to Nigerian Freshwater Fishes. Federal College of 
Freshwater Fisheries Technology, New Bussa, Nigeria.

Oribhabor, B.J., Ogbeibu, A.E. 2010. The ecological impacts of anthropogenic activities on the predatory fish assemblage of a tidal creek in the Niger Delta, Nigeria. Research Journal of Environmental Sciences, 4: 271-279.

Oribhabor, B.J., Ogbeibu, A.E. 2009a. Concentration of heavy metals in a Niger Delta Mangrove Creek, Nigeria. Global Journal of Environmental Sciences, 8: $63-68$.

Oribhabor, B.J., Ogbeibu, A.E. 2009b. The ecological impact of anthropogenic activities on the macrobenthic invertebrates of a mangrove creek in the Niger Delta, Nigeria. Asian Journal of Microbiology, Biotechnology and Environmental Sciences, 11: 513-524.

Oribhabor, B.J., Ezenwa, B.I.O., Ogbeibu, A.E. 2005. Brackish water fish resources of Nigerian coastal zones: The need for protection and extension of brackish water aquaculture. In: Proceedings of the $20^{\text {th }}$ Annual Conference of the Fisheries Society of Nigeria (FISON), $14^{\text {th }}-18^{\text {th }}$ November 2005, pp. 95-102, Port Harcourt, Rivers State, Nigeria.

Oribhabor, B., Ezenwa, B. 2005. Inventory of fisheries and fishes of the Lagos Lagoon, Lagos, Nigeria. Tropical Freshwater Biology, 14: 19-36.

Okereke, F.O. 1990. Studies on the Ichthyofauna of Otamiri River in Imo State, Nigeria.MSc. Thesis, University of Port Harcourt, Nigeria.
Schneider, W. 1990. FAO Species Identification Sheets for Fishery Purpose-Field Guide to the Commercial Marine Resources of the Gulf of Guinea. Food and Agricultural Organization of the United Nations, Rome, Italy.

Sheridan, P., Hays, C. 2003. Are mangroves nursery habitat for transient fishes and decapods? Wetlands, 23: 449-458.

Spalding, M., Blasco, F., Field, C.D. 1997. World Mangrove Atlas, 178 pp., The International Society for Mangrove Ecosystem (ISME), Okinawa, Japan.

Teugels, G.G., Reid, G., King, R.P. 1992. Fishes of the Cross River Basin (Cameroun-Nigeria) taxononomy, zoogeography, ecology and conservation. Annales Sciences Zoologiques, 266, 132 pp., Musee Royal de L'Afrique Centrale.

Tongnunui, P., Ikejima, K., Yamane, T., Horinouchi, M., Medej, T., Sano, M., Kurokura, H., Taniuchi, T. 2002. Fish fauna of the Sikako creek mangrove estuary, Trang, Thailand. Fisheries Science, 68: 10-17.

Walters, B.B., Ronnback, P., Kovacs, J.M., Crona, B., Hussain, S.A., Badola, R., Primavera, J.H., Barbier, E., Dahdouh-Guebas, F. 2008. Ethnobiology, socioeconomics and management of mangrove forests. A review. Aquatic Botany, 89: 220-236.

Wright, J.M. 1986. The ecology of fish occurring in shallow water creeks of Nigerian mangrove swamp. Journal of Fish Biology, 29: 431-441. 